\section{NIH merger to shorten review}

\section{Washington}

THE Recombinant DNA Advisory Committee (RAC) of the US National Institutes of Health (NIH) voted unanimously last week to disband its human gene therapy subcommittee. The move will reduce, from six to five, the number of regulatory hoops researchers must jump through to obtain approval of federally funded experiments. It also resolves a communications gap between the two groups, which had some overlapping membership but which occasionally reached different conclusions about whether a specific experiment should be allowed.

RAC was set up by the NIH in 1975 to provide oversight for federally funded experiments involving the use of recombinant DNA technology. Before long, however, it became clear that many types of experiments, including the deliberate release into the environment of genetically engineered organisms, posed minimal risk to human health and the environment. Now, 17 years later, many of RAC's earlier responsibilities have either been deregulated or come under the aegis of other government agencies or local review boards.

In 1984 the RAC established what is now called the human gene therapy subcommittee to address the specific technical and scientific issues raised by experiments involving gene transfer and gene therapy in humans. It is because RAC and its gene subcommittee now perform much the same role that LeRoy Walters, a bioethicist from Georgetown University and chair of the gene subcommittee, thinks it is a "logical time to make this step".

By streamlining the process into a single review at this level, RAC hopes to become faster and more efficient and end the poor communication that existed be- tween the two panels. With no guarantee full voting members of RAC, however, some members are worried that the parent committee could find itself lacking the expertise necessary to review experiments of this kind.

Researchers are also frustrated by the amount of duplication within the twotiered system. Even though six members of the subcommittee also hold seats on the RAC, the lack of communication between the two committees has made it necessary for researchers to present the same data to both the gene subcommittee and the RAC and then to undergo two quite separate reviews. Martin Gellert, a laboratory chief in the metabolic enzymes section of the National Institute of Diabetes and Digestive and Kidney Diseases within the NIH and a member of both committees, admits the system broke down because there was "no mechanism for transmitting detailed discussions of the gene therapy subcommittee to the RAC'.

Although the RAC has recommended that members of the subcommittee who are not also members of the parent committee should be appointed to the RAC, the final decision is out of RAC's hands. All nominations must be approved at the secretarial level of the department of Health and Human Services. Gellert believes that in the interim this could leave RAC short on technical and scientific know-how as there was a higher representation of scientists with knowledge of human gene therapy on the subcommittee. "Right now, the RAC is a little bit short on that kind of expertise", he says.

To compensate for the lack of preliminary review, RAC has agreed to increase the number of annual meetings from three to as many as six.

Diane Gershon that subcommittee members will be made

\section{Airlines vs activists \\ Washington}

Northwest Airlines, declaring that it "had no way to judge the merits of [animal rights] arguments", last week resumed shipments of laboratory animals after suspending them last fall because of protests from animal activists. The decision ends the company's self-appointed but naive attempt to become an arbiter in the bitter controversy over the use of animals in research.

Jon Austin, a spokesman for the company, which is based in Minneapolis, Minnesota, says that officials debated the issue for several weeks and found that the arguments "were equally compelling on both sides". They decided that the subject should be resolved by governmental bodies, not private companies. In the meantime, Austin says, Northwest is reverting to its original policy of accepting shipments that are "safe and legal".

In November the company decided to suspend its delivery of some 160 beagles to a Swiss laboratory, where they were to be used in toxicity experiments. Animal rights groups, including Friends of Animals, took credit for the action, which they said was part of a campaign to eliminate the use of animals in research. Austin had announced then that Northwest was "going to try to figure out what the socially responsible thing to do is."

The temporary ban triggered a letterwriting campaign from researchers around the United States, including several scientists at the Mayo Clinic in nearby Rochester, Minnesota. The airline received some 500 letters and phone calls on the issue, divided equally between supporters and opponents of animal research.

One surprising participant in the debate was a former presidential candidate, Walter Mondale, who sits on the board of directors of both the Mayo Clinic and Northwest. Ross Corson, a spokesman for Mondale, confirmed that Mondale conveyed the feelings of Mayo researchers to his fellow board members at Northwest. "He asked them to review their policy", says Corson.

The airline was handicapped by its lack of knowledge, according to Austin. "We would hear from somebody who was a member of the National Academy of Sciences, in support of animal research, and then we would hear from somebody else, with equally impressive credentials, arguing the opposite view," he says. "And we were stuck in the middle, lacking the credentials to make a decision."

Austin says that the decision to resume shipments does not mean that Northwest supports the use of animals in research, only that "we decided our responsibility was to follow the law, as it is currently written."

Jeffrey Mervis pinced by undecided voters were con- 